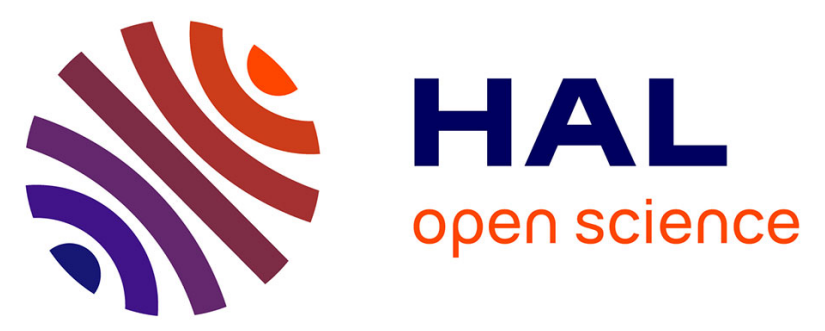

\title{
Pinnularia schoelynckiana, a new limnoterrestrial diatom species (Bacillariophyta) from the sub-Antarctic Iles Kerguelen (southern Indian Ocean)
}

\author{
Bart van de Vijver, Pieter Scholberg, Marc Lebouvier
}

\section{- To cite this version:}

Bart van de Vijver, Pieter Scholberg, Marc Lebouvier. Pinnularia schoelynckiana, a new limnoterrestrial diatom species (Bacillariophyta) from the sub-Antarctic Iles Kerguelen (southern Indian Ocean). Botany Letters, 2020, 167 (1), pp.42-49. 10.1080/23818107.2019.1675185 . hal-02391114

HAL Id: hal-02391114 https://hal-univ-rennes1.archives-ouvertes.fr/hal-02391114

Submitted on 17 Feb 2020

HAL is a multi-disciplinary open access archive for the deposit and dissemination of scientific research documents, whether they are published or not. The documents may come from teaching and research institutions in France or abroad, or from public or private research centers.
L'archive ouverte pluridisciplinaire HAL, est destinée au dépôt et à la diffusion de documents scientifiques de niveau recherche, publiés ou non, émanant des établissements d'enseignement et de recherche français ou étrangers, des laboratoires publics ou privés. 
Pinnularia schoelynckiana, a new limnoterrestrial diatom species (Bacillariophyta) from the sub-Antarctic Iles Kerguelen (southern Indian Ocean)

Bart Van de Vijver ${ }^{1,2}$, Pieter Scholberg ${ }^{1,2}$ and Marc Lebouvier ${ }^{3}$

${ }^{1}$ Meise Botanic Garden, Research Department, Nieuwelaan 38, B-1860 Meise, Belgium

${ }^{2}$ University of Antwerp, Department of Biology, ECOBE, Universiteitsplein 1, B-2610

Wilrijk, Belgium

${ }^{3}$ UMR 6553 Ecobio CNRS, Université de Rennes 1, Station Biologique, F-35380 Paimpont, France 


\begin{abstract}
An unknown Pinnularia taxon was recorded during a survey of the limno-terrestrial diatom flora of some hot springs in the Val Travers area (Grand Terre, Iles Kerguelen, sub-Antarctic region). The morphology of the species was investigated using both light and scanning electron microscopy. Based on these results, the species could not be identified using the currently available literature and is therefore described as a new species: Pinnularia schoelynckiana sp. nov. The new species is characterized by rhombic-lanceolate valves, radiate, geniculate striae changing into strongly convergent near the apices and an undulating, lateral raphe. A detailed morphological comparison is made with similar Pinnularia species, described from the Antarctic Region and worldwide. Brief notes on the associated diatom flora and its ecology are added.
\end{abstract}

Key-words: Pinnularia, sub-Antarctica, morphology, new species, hot springs. 


\section{Introduction}

For more than 100 years, the non-marine diatom flora of the sub-Antarctic Iles Kerguelen, a large archipelago in the southern Indian Ocean, has been the subject of several taxonomic studies. Although the first data were already published by Reinsch $(1876,1879)$ and Hemsley (1885), it was not until the contributions by Germain (1937) and Bourrelly and Manguin (1954) that the sub-Antarctic diatom flora of the archipelago became better known. Both papers described a large number of new taxa, despite being based on only a handful of samples. The first large overview of the Kerguelen diatom flora was later made by Le Cohu and Maillard (1983, 1986) who analyzed more than 75 samples from different parts of Iles Kerguelen, describing several of the observed species as new. Despite these publications, the non-marine diatom flora of the sub-Antarctic Region was still considered as being largely composed of cosmopolitan species (Jones 1996; Van de Vijver and Beyens 1999). Kellogg and Kellogg (2002) listed all reported taxa from Antarctica showing that most had a rather broad geographic distribution. A large taxonomic effort, revising the entire Antarctic nonmarine diatom flora started almost 20 years ago, contradicting the general idea of a cosmopolitan flora in the sub-Antarctic region. Van de Vijver, Frenot, and Beyens (2002) revised the diatom flora of the nearby Iles Crozet and together with the transfer of twenty taxa (mainly described by Germain (1937) and Manguin in Bourrelly and Manguin (1954)), described another 37 new taxa, a lot of which are still recognized as being typical subAntarctic endemics, never found outside the sub-Antarctic Region (Van de Vijver, Frenot and Beyens, 2002; Van de Vijver, Gremmen and Beyens 2005; Zidarova, Kopalová and Van de Vijver 2016). Later studies on the sub-Antarctic Heard Island (Van de Vijver et al. 2004a) and the Prince Edward Islands (Van de Vijver, Gremmen, and Smith 2008) confirmed the presence of a typical sub-Antarctic diatom flora. Since 2010, almost every year, new taxa are added to the sub-Antarctic flora (e.g. Romero and Van de Vijver 2011; Van de Vijver 2012, 
2014, 2019; Van de Vijver and Dessein 2018; Van de Vijver, de Haan, and Lange-Bertalot 2014; Van de Vijver et al. 2017, Van de Vijver, Wetzel, and Ector 2018).

During a survey of the diatom communities of the hot spring area of Val Travers in the central part of the Iles Kerguelen's main island, an unknown Pinnularia species was found that could not be identified using the currently available literature. In the past, this genus proved to be very species-rich in the entire Antarctic area with more than 50 new taxa (including species and varieties) described the past 65 years (Bourrelly and Manguin 1954, Van de Vijver, Frenot and Beyens 2002; Van de Vijver et al. 2012; Van de Vijver and Zidarova 2011; Zidarova, Kopalová and Van de Vijver 2012). Based on detailed light and scanning electron microscopy observations, the new species is described as Pinnularia schoelynckiana sp. nov. The new species is compared with similar Pinnularia species worldwide, mainly with species found in the southern hemisphere. Notes on its ecology and its biogeographical distribution in the sub-Antarctic region are added.

\section{Material and methods}

The French Iles Kerguelen $\left(49^{\circ} \mathrm{S}, 69^{\circ} \mathrm{E}\right)$ is a large archipelago located in the southern Indian Ocean, ca. $4000 \mathrm{~km}$ from the coasts of South Africa and Australia. The archipelago, covering a total land area of $7215 \mathrm{~km}^{2}$, is composed of more than 300 smaller and larger islands of which the main island, Grande Terre, is the largest of all $\left(6500 \mathrm{~km}^{2}\right)$. The island is mountainous, with the highest peak culminating at $1850 \mathrm{~m}$ a.s.l. It has an oceanic cold climate with a mean annual temperature at the Port-aux-Français weather station of $4.9^{\circ} \mathrm{C}$, with 8.2 ${ }^{\circ} \mathrm{C}$ (February) and $2.1^{\circ} \mathrm{C}$ (July) for the warmest and coldest month respectively (Météo France Data, 1951-2017). Wind speed is generally high. Annual rainfall varies from less than $800 \mathrm{~mm}$ in the eastern part to more than $3200 \mathrm{~mm}$ on the western coast (Frenot et al., 1997), mainly in the form of rain. 
The study area, Val Travers, is situated in the center of the main island Grand Terre $\left(69^{\circ} 25^{\text {' }}\right.$ S, $49^{\circ} 19^{\prime}$ E, $40 \mathrm{~m}$ a.s.l.) and contains one of the last remaining expressions of the ancient volcanic history of the archipelago. During a short stay in the austral summer of 2004-2005, a total of 24 moss samples has been collected on a transect starting close to a hot spring along the river that runs through Val Travers. At this place, the water temperature of the hot spring was $62{ }^{\circ} \mathrm{C}$ whereas the temperature in the mosses varied between 18 and $20{ }^{\circ} \mathrm{C}$ (measurements done on 31/01/2005). The new Pinnularia species was observed in several of the samples with the largest population being present in the immediate vicinity of the hot spring in sample B-3, the latter thus selected for further light and scanning electron microscopy observations.

The samples were prepared for LM observation following the method described in van der Werff (1955). Small parts of the samples were cleaned by adding $37 \% \mathrm{H}_{2} \mathrm{O}_{2}$ and heating to $80^{\circ} \mathrm{C}$ for about $1 \mathrm{~h}$. The reaction was completed by addition of $\mathrm{KMnO}_{4}$. Following digestion and centrifugation (three times 10 minutes at $3700 \mathrm{x}$ g), cleaned material was diluted with distilled water to avoid excessive concentrations of diatom valves on the slides. Cleaned diatom material was mounted in Naphrax. Slides were analyzed using an Olympus BX53 microscope, equipped with Differential Interference Contrast (Nomarski) and the Olympus UC30 Imaging System. Samples and slides are stored at the BR-collection (Meise Botanic Garden, Belgium). For scanning electron microscopy (SEM), parts of the oxidized suspensions were filtered through a 1- $\mu \mathrm{m}$ Isopore ${ }^{\mathrm{TM}}$ polycarbonate membrane filter (Merck Millipore). The stubs were sputter-coated with a Gold-Palladium layer of $20 \mathrm{~nm}$ and studied in a JEOL-JSM-7100F scanning electron microscope at $1 \mathrm{kV}$ at the Meise Botanic Garden, Belgium. Diatom terminology follows Ross et al. (1979) (stria and areola morphology), Krammer (2000) (overall genus morphology) and Round, Crawford, and Mann (1990) (raphe structure). The morphology of the new taxon has been compared with all known Pinnularia 
species described worldwide (i.a. Bourrelly and Manguin 1954; Le Cohu and Maillard 1986; Krammer 2000; Rumrich, Lange-Bertalot and Rumrich 2000; Van de Vijver, Frenot and Beyens 2002; Van de Vijver et al. 2012; Zidarova, Kopalová and Van de Vijver 2012).

\section{Results}

Pinnularia schoelynckiana Van de Vijver, Scholberg \& Lebouvier, sp. nov. (Figs 1-26)

Description. LM(Figs 1-19): Frustules in girdle view rectangular (Fig. 1). Valves rhombiclanceolate with weakly convex, never parallel margins and protracted, weakly capitate apices. Valve dimensions ( $n=25)$ : length 53-60 $\mu \mathrm{m}$, width 7.5-8.5 $\mu \mathrm{m}$. Axial area very narrow near the apices, gradually but distinctly widening towards the central area. Central area relatively large, forming a wedge-shaped fascia. Shortened striae never observed in the central area. Raphe lateral, with clearly undulating raphe branches. Central raphe endings expanded, droplike, weakly unilaterally deflected, rather distant from each other. Terminal raphe fissures elongated, hooked. Striae distinctly radiate and geniculate near the central area, becoming strongly convergent near the apices, 10-11 in $10 \mu \mathrm{m}$. Striae bordering the central area abruptly shortening. Longitudinal lines absent.

SEM (Figs 20-26): Mantle striae continuing till halfway the mantle leaving the mantle edge hyaline (Fig. 21). Alveoli composed of 5-6 rows of small areolae (Figs 20, 22 and 23). External raphe branches clearly undulating (Fig. 20). Central raphe endings asymmetrically expanded, almost spatulate. Raphe itself strange but spatulate expansion laterally deflected (Fig. 22). Terminal raphe fissures elongated, hooked, continuing onto the mantle (Fig. 23). Internally, raphe interrupted at the central nodule with inconspicuous, straight to weakly deflected central endings (Figs 24 and 25). Terminal endings terminating on distinct helictoglossae (Fig. 26). Alveoli opening via narrow fenestra to the valve interior (Figs 2426). Virgae between the alveoli rather narrow, clearly raised. (Fig. 26). 
Holotype. BR-4569 (Meise Botanic Garden, Belgium)

Isotype. PLP-363 (University of Antwerp, Belgium)

Type locality. Val Travers, Grande Terre, Iles Kerguelen, sub-Antarctic region, sample B-3, (leg. M. Lebouvier, coll. date 31/01/2005)

Etymology. The species is named in honour of our colleague, Dr. Jonas Schoelynck (Ecosystem Management Research Group (ECOBE), University of Antwerp, Belgium) in recognition of his work on the silicium cycle in aquatic environments.

Associated diatom species. The samples in which P. schoelynckiana were found, proved to be quite species rich. The holotype slide was dominated by Fragilaria cf. capucina Desmazières (21\%), Psammothidium abundans (Manguin) Bukhtiyarova \& Round (16\%) and Gomphonema cf. montanum Schumann (16\%). Other associated taxa include Achnanthidium sieminskae Witkowski et al., A. modestiforme (Lange-Bertalot) Van de Vijver, Brachysira sandrae Van de Vijver, Chamaepinnularia muscicola (J.B.Petersen) Kulikovskiy, LangeBertalot \& Witkowski, Eunotia mourotii Van de Vijver et al., Kobayasiella subantarctica Van de Vijver \& Vanhoutte, and several Psammothidium taxa.

Ecology and distribution. Pinnularia schoelynckiana was found in several moss samples collected in some brooks and rivers in the Val Travers area (Kerguelen). The largest population was observed in sample B-3, a liverwort sample collected from the main hotspring at $70 \mathrm{~m}$ altitude with a water temperature of $62.4^{\circ} \mathrm{C}$. Although no physico-chemical measurements were performed at the time of sampling, the environmental characteristics of the area can be derived from data collected in 2011 and published by Parikka et al. (2018). In the paper, they indicate a clearly alkaline pH (8.1-9.8), a moderate conductivity (265 $\mu \mathrm{S} / \mathrm{cm})$ and very high $\mathrm{SO}_{4}{ }^{2-}\left(146-152 \mu \mathrm{mol} \mathrm{L}{ }^{-1}\right)$ and $\mathrm{Cl}^{-}\left(613-630 \mu \mathrm{mol} \mathrm{L}{ }^{-1}\right)$ values. 
The species was so far not observed on other sub-Antarctic localities. Le Cohu and Maillard (1986, fig. 58 under the name $P$. rivularis Hustedt) observed the species in several rivers on Grand Terre, Iles Kerguelen, indicating that the species might have a broader distribution area on the archipelago thriving in mosses and algae in flowing waterbodies.

\section{Discussion}

Analysis of all Pinnularia species described from the sub-Antarctic region indicated several species that showed some similarities with the new P. schoelynckiana. Bourrelly and Manguin (1954) described P. circumducta Manguin from a peat sample. Although the authors indicated the species as being 'rare' in the sample, an attempt was made to analyse all slides made from the material. Unfortunately, specimens belonging to $P$. circumducta were never found (Van de Vijver et al. 2004b). Le Cohu (1981) illustrated valves presumably belonging to $P$. circumducta but careful analysis revealed the presence of spines at the apices and in the central area. The latter species was in 2004 described as $P$. sofiae Van de Vijver \& Le Cohu (Van de Vijver et al. 2004b). Pinnularia sofiae clearly differs in its parallel striation, the presence of spines at the apices and in the central area and the broad rectangular fascia (Van de Vijver et al. 2004b), all features that have never been observed in P. schoelynckiana. The only illustration of $P$. circumducta is most likely fig. 74 in Le Cohu and Maillard (1986), although it could not be confirmed using the type material. Pinnularia circumducta shows a relatively similar valve outline, although the apices of $P$. schoelynckiana seem to be narrower than in P. circumducta. Important differences however are the presence of a longitudinal line on $P$. circumducta, as drawn by Manguin (Bourrelly and Manguin 1954, fig. 51) that is absent in $P$. schoelynckiana and a different striation pattern in the central area. In $P$. circumducta, the striae bordering the central area are hardly shortened whereas in P. schoelynckiana, the striae near the central area are gradually shortening. Finally, the terminal raphe fissures in $P$. 
circumducta seem to be clearly sickle-shaped, terminating on the valve face whereas in $P$. schoelynckiana the terminal fissures are hooked and continue clearly onto the mantle. Another sub-Antarctic taxon, P. subantarctica var. elongata (Manguin) Van de Vijver \& Le Cohu, showing a similar valve outline, differs in having longitudinal lines on its striae and non-shortened striae bordering the central area (Van de Vijver, Frenot, and Beyens 2002). Le Cohu and Maillard (1986, fig. 58) illustrated a Pinnularia valve that seems to be identical to the new species and identified it as $P$. rivularis Hustedt, described from Java (Simonsen 1987). However, analysis of the type specimens of P. rivularis depicted in Simonsen (1987, p. 160, pl. 255, figs 3-5) revealed that the latter is entirely different and shows no similarity with the Kerguelen specimen illustrated by Le Cohu and Maillard (1986). Other similar Pinnularia taxa in the sub-Antarctic region could not be found.

Several other Pinnularia taxa worldwide show some similarity to the new $P$. schoelynckiana. These include $P$. similis Hustedt, $P$. similiformis Krammer, $P$. diversa Østrup and $P$. lunata Krammer \& Lange-Bertalot.

Pinnularia similis was described by Hustedt from Java in 1934 (Schmidt 1934). Simonsen (1987, plate 244, fig. 5) illustrated the lectotype adding a second, morphologically rather different, specimen as isolectotype (plate 244, figs 3 \& 4). The valve dimensions of both taxa are similar. The drawings in Schmidt (1934, pl. 385, figs 10-12) however show a more slender, linear-lanceolate valve outline, contrary to the more rhombic-lanceolate outline in $P$. schoelynckiana. Additionally, the change in stria orientation occurs in P. similis almost halfway between central area and apex whereas in P. schoelynckiana, this change is positioned much closer to the valve apices. The central raphe endings are also much closer together in $P$. similis, continuing further into the central area. In P. schoelynckiana, the central endings are rather distant and terminate just slightly beyond the last striae bordering the 
central area. The striae are more geniculate in $P$. schoelynckiana whereas in $P$. similis they seem to be almost straight.

Pinnularia similis is a worldwide reported taxon. Unfortunately, most reports only mention the name lacking illustrations making it very difficult to verify whether the reported population/valves actually represent the true $P$. similis. A population from Uruguay (Metzeltin, Lange-Bertalot, and García-Rodríguez 2008) that was identified as P. similis, shows broader valves, a more undulating raphe and broadly rounded, subcapitate apices, making it less likely to be conspecific with $P$. similis sensu stricto. The Uruguayan population differs from $P$. schoelynckiana in having broader apices, a clearly undulating, lateral raphe and a smaller central area where a fascia is occasionally lacking (Metzeltin, Lange-Bertalot, and García-Rodríguez 2008, plate 172). Bourrelly and Manguin (1952, fig. 121) show in a sample from Guadeloupe, a more lanceolate (and clearly not linear) valve with narrow apices contrary to $P$. similis s.s. Pinnularia similis fo. recta, described from Guadeloupe in the same paper, is narrower than $P$. schoelynckiana with a strictly linear valve outline showing parallel, straight, never convex margins as is the case in P. schoelynckiana (Bourrelly and Manguin, 1952, fig. 122). Compère (1975, fig. 265) also shows a valve that is neither conspecific with $P$. similis (central area much larger, valve margins straight) nor with $P$. schoelynckiana (central area much larger, no shortened striae, valve margins never convex, apices too narrow). Other records such as Delgado and Souza (2007), Foged (1971), Frenguelli (1942, 1953), Fujita \& Ohtsuka (2005), Guermeer (1954), Krasske (1943), Le Cohu and Maillard (1986), Souza and Senna (2009), Tynni (1976, 1991) show valves that should be distinguished from both $P$. similis and $P$. schoelynckiana based on valve outline, shape and size of the apices or shape of the central area. It is clear that a revision of all these $P$. similis populations will be needed to establish the correct biogeography of the latter species and that most of these observations are the result of a clear force-fitting of the (South) American, 
African and European populations into P. similis from Java (Tyler 1996). Pinnularia aff. similis reported by Lange-Bertalot and Metzeltin (2009) from Panama shows some similarity with $P$. schoelynckiana but can be differentiated by a more undulating valve outline, a slightly larger central area and a clearly undulating raphe. Krammer (2000) separated smaller valves as $P$. similiformis that can be distinguished from $P$. schoelynckiana in having narrower valves (5.3-6.5 $\mu \mathrm{m}$ vs. 7.5-8.5 $\mu \mathrm{m}$ in P. schoelynckiana) and shorter, straight striae. Pinnularia diversa was described from the Färöes Islands (Østrup 1901) but is much smaller with narrower valves (max. width up to $6 \mu \mathrm{m}$ ) showing a very abrupt change in stria orientation in the middle between the central area and the apices (Krammer 2000). Finally, Pinnularia lunata, a species found in Siberia (Lange-Bertalot and Genkal 1999), shows typical depressions in the axial and central area that are absent in P. schoelynckiana. The Siberian species is also shorter but has a higher valve width (up to $9.5 \mu \mathrm{m}$ ) compared to $P$. schoelynckiana (Lange-Bertalot and Genkal 1999).

The description of the new Pinnularia species confirms the special interest of the hot spring area in Val Travers. In 2014, a new Brachysira species, B. sandrae, was described forming relatively large populations in the Val Travers samples, despite being absent in the rest of the sub-Antarctic region (Van de Vijver 2014). Only on the sub-Antarctic islands in the Pacific Ocean (Macquarie Island, Campbell Island), other Brachysira species were observed (Van de Vijver, unpubl. results). The samples in Val Travers also contain large populations of Frustulia lebouvieri Van de Vijver \& Gremmen, a species described from the Prince Edward Islands (Van de Vijver and Gremmen 2006) and only also found on Ile Amsterdam (Chattová, Lebouvier, and Van de Vijver 2014).

\section{Acknowledgements}


Sampling on Kerguelen has been made possible thanks to the logistic and financial support of the French Polar Institute-Paul-Emile Victor in the framework of the research program 136 (Marc Lebouvier and Yves Frenot). Prof. Luc Ector and an anonymous reviewer are thanked for their excellent help in ameliorating this manuscript.

\section{Disclosure statement}

No potential conflict of interest was reported by the authors.

\section{Notes on contributors}

Bart Van de Vijver is a full-time researcher at the Meise Botanic Garden, Belgium, and a part-time professor at the University of Antwerp, Belgium. His research focuses mainly on the taxonomy, morphology and biogeography of Antarctic freshwater and terrestrial diatoms. He has been studying non-marine diatoms in various parts of the Antarctic region for more than 20 years. He has described almost 400 new taxa and revised an additional 250 taxa. Contribution: identification of diatom species, discussion of results and writing and editing of the manuscript.

Pieter Scholberg is a master student at the University of Antwerp making his Individual Project at the Meise Botanic Garden, Belgium under supervision of B. Van de Vijver. Contribution: identification and photographing of the species, discussion of results.

Marc Lebouvier is a research engineer at the CNRS (Centre National de la Recherche Scientifique). He carries out his research in the program 136 "Subantarctic biodiversity, effects of climate change and biological invasions on terrestrial biota" supported by the 
French Polar Institute : field work and sampling at Iles Kerguelen in 2005, discussion of results and reviewing of the manuscript.

Contribution: field work and sampling at Iles Kerguelen in 2005, discussion of results and reviewing of the manuscript.

\section{References}

Bourrelly, P., and E. Manguin 1952. Algues d'eau douce de la Guadeloupe et dépendances recueillies par la Mission P. Allorge en 1936. Centre National de la Recherche Scientifique, Société d'Edition d'Enseignement Supérieur, Paris. 281 pp.

Bourrelly, P., and E. Manguin 1954. “Contribution à la flore algale d’eau douce des Iles Kerguelen.” [Contribution to the Freshwater Algal Flora of Iles Kerguelen] Mémoires de l’Institut Scientifique de Madagascar, Série B, Biologie Végétale 5: 7-58.

Chattová B., M. Lebouvier, and B. Van de Vijver 2014. “Freshwater diatom communities from Ile Amsterdam (TAAF, southern Indian Ocean).” Fottea 14: 101-119.

doi:10.5507/fot.2014.008.

Compère, P. 1975. “Algues de la Région du Lac Tchad. IV. Diatomophycées.” Cahiers O.R.S.T.O.M., série Hydrobiologie IX : 203-290.

Delgado, S.M., and M. Souza 2007. "Diatomoflórula Perifítica do rio Descoberto - DF e GO, Brasil, Naviculales (Bacillariophyceae): Diploneidineae e Sellaphorineae”. Acta botanica brasiliensis 21: 767-776.

Foged, N. 1971. “Freshwater diatoms in Thailand.” Nova Hedwigia 22: 1-54.

Frenguelli, J. 1942. “Diatomeas del Neuquen ( Patagonia).” Revista del Museo de la Plata, Nueva Serie, Sección Botánica 5(20):73-219.

Frenguelli, J. 1953. 'Diatomeas del Territorio Nacional de Misiones.’ Revista del Museo de la Ciudad Eva Peron, nueva serie, Sección Botánica 8: 63-86. 
Frenot, Y., J.C. Gloaguen, B. Van de Vijver, and L. Beyens 1997. "Datation de quelques sédiments tourbeux holocènes et oscillations glaciaires aux îles KerguelenDatation of some Holocene peat sediments and glacier fluctuations in the Kerguelen Islands.” [Datation of some holocene peat sediments and glacier fluctuations in the Kerguelen islands]. Comptes Rendus de l'Académie des Sciences de Paris, Series III, Sciences de la Vie / Life Sciences 320: 567-573. doi:10.1016/S0764-4469(97)84712-9.

Fujita, Y., and T. Ohtsuka 2005. “Diatoms from paddy fields in northern Laos.” Diatom. The Japanese Journal of Diatomology 21: 71-89.

Germain, H. 1937. “Diatomées d’une tourbe de l'île Kerguelen.” [Diatoms of a peat from Iles Kerguelen] Bulletin de la Société Française de Microscopie 6: 11-16.

Guermeer, P. 1954. “Diatomées de L'Afrique Occidentale Française (Première Liste: Sénégal). ” Institut Français D'Afrique Noire. Catalogues, Ifan-Dakar 12: 1-137. Hemsley, W.B. 1885. Report on the botany of the Bermudas and various other islands of the Antarctic and Southern Oceans. Report on the scientific results of the Voyage of the H.M.S. Challenger during 1873-1876, Botany I (part 2), 299 pp.

Jones, V.J. 1996. “The diversity, distribution and ecology of diatoms from Antarctic inland waters.” Biodiversity and Conservation 5: 1433-1449. doi:10.1007/BF00051986.

Kellogg, T.B., and D.E. Kellogg 2002. "Non-marine and littoral diatoms from Antarctic and sub-Antarctic regions. Distribution and updated taxonomy.” Diatom Monographs 1: 1-795. Krammer, K. 2000. “The genus Pinnularia.” Diatoms of Europe 1: 1-703.

Krasske, G. 1943. “Zur Diatomeenflora Lapplands. ” Bericht der Deutschen Botanischen Gessellschaft 61(3): 81-88.

Lange-Bertalot, H., and S.I. Genkal 1999. “Diatomeen aus Sibirien I - Inseln im Arktischen Ozean (Yugorsky-Shar Strait).” [Diatoms from Siberia I - Islands in the Arctic Ocean (Yugorsky-Shar Strait)] Iconographia Diatomologica 6: 1-271. 
Lange-Bertalot, H., and D. Metzeltin 2009. “A dystrophic mountain lake in Panama - Hot spot of new and rare neotropical diatoms.” Nova Hedwigia, Beiheft 135: 137-166.

Le Cohu, R. 1981. “Les espèces endémiques de diatomées aux Iles Kerguelen.” [Endemic species of diatoms in Iles Kerguelen] Comité National Français de Recherches Antarctiques 51: 35-42.

Le Cohu, R., and R. Maillard 1983. “Les diatomées monoraphidées des îles Kerguelen.” [Monoraphid diatoms of Iles Kerguelen] Annales de Limnologie 19: 143-167. doi: 10.1051/limn/1983018.

Le Cohu, R., and R. Maillard 1986. “Diatomées d’eau douce des îles Kerguelen (à l’exclusion des Monoraphidées).” [Freshwater diatoms of Iles Kerguelen (excluding Monoraphids)] Annales de Limnologie 22: 99-118. doi: 10.1051/limn/1986018.

Metzeltin, D., H. Lange-Bertalot, and F. García-Rodríguez 2008. “Diatoms of Uruguay. Compared with other taxa from South America and elsewhere.” Iconographia Diatomologica 15: $1-736$.

Østrup, E. 1901. “Freshwater diatoms.” In: Botany of the Faeröes based upon Danish investigations Part 1: 260-290. Copenhagen \& London: Det. Nordiske Forlag; John Wheldon \& Co.

Parikka, K.J., S. Jacquet, J. Colombet, D. Guillaume, and M. Le Romancer 2018. “Abundance and observations of thermophilic microbial and viral communities in submarine and terrestrial hot fluid systems of the French Southern and Antarctic Lands.” Polar Biology 41: 1335-1352. Reinsch, P.F. (1876) "Species ac genera nova algarum aquae dulcis quae sunt inventa in speciminibus in Expedition 'Vener' transit hieme 1874-1875, in insula Kerguelensi a clar. Eaton collectis.” Linnean Society Journal of Botany 15: 205-221. Reinsch, P.F. 1879. "Fresh-water algae collected by the Rev. A.E. Eaton. Algae 
aquae dulcis Insulae Kerguelensis. An account of the petrological, botanical and zoological collections made in Kerguelen’s Land and Rodriquez during the transit of Venus expeditions, carried out by order of her Majesty’s Government in the years 1874-75.” Philosophical Transaction of the Royal Society of London 168: 65-92.

Romero, O.E., and B. Van de Vijver 2011. “Cocconeis crozetensis, a new monoraphid diatom from subantarctic freshwater and moss habitats.” Diatom Research 26: 89-98. doi: 10.1080/0269249X.2011.575118.

Ross, R., E.J. Cox, N.I. Karayeva, D. G. Mann, T.B.B. Paddock, R. Simonsen, and P.A. Sims. 1979. “An amended terminology for the siliceous components of the diatom cell.” Nova Hedwigia, Beihefte 64: 513-533.

Round, F.E., R.M. Crawford, and D.G. Mann. 1990. The Diatoms. Biology and Morphology of the Genera. Cambridge: Cambridge University Press.

Rumrich, U., H. Lange-Bertalot, and M. Rumrich 2000. “Diatomeen der Anden Von Venezuela bis Patagonien/Feuerland.” [Diatoms of the Andes. From Venezuela to Patagonia/Tierra del Fuego] Iconographia Diatomologica 9: 1-649.

Schmidt, A. (1934). Atlas der Diatomaceenkunde Series VIII: Heft 97-98: pls 385-392. . Leipzig: O.R. Reisland.

Simonsen, R. 1987. Atlas and Catalogue of the Diatom Types of Friedrich Hustedt. J. Berlin \& Stuttgart: J. Cramer: 525 pp.

Souza, M., and P. Senna 2009. “Diatomáceas epilíticas da subordem Sellaphorineae do rio do Monjolinho, São Carlos, SP, Brasil.” Acta botanica brasiliensis 23: 618-629.

Tyler, P.A. 1996. "Endemism in freshwater algae, with special reference to the Australian region.” In: Biogeography of freshwater algae (Ed. by J. Kristiansen). Hydrobiologia 336: 127-135. https://doi.org/10.1007/BF00010826 
Tynni, R. 1976. “Über Finnlands rezente und subfossile Diatomeen, IX.” Geological Survey of Finland 284: 1-74.

Tynni, R. 1991. “Diatoms from Lake Pulmankijärvi, northern Finland and the coast of Varangerfjorden, northern Norway.” Geological Survey of Finland, Report of Investigation 106: $1-34$.

Van de Vijver, B., and L. Beyens 1999. “Biogeography and ecology of freshwater diatoms in Subantarctica: a review.” Journal of Biogeography 26: 993-1000 (doi: 10.1046/j.13652699.1999.00358.x).

Van de Vijver, B., Y. Frenot, and L. Beyens 2002. "Freshwater diatoms from Ile de la Possession (Crozet Archipelago, Subantarctica).” Bibliotheca Diatomologica 46: 1-412. Van de Vijver, B., L. Beyens, S. Vincke, and N.J.M. Gremmen 2004. “Moss-inhabiting diatom communities from Heard Island, sub-Antarctic.” Polar Biology 27: 532-543. doi:10.1007/s00300-004-0629-x. Van de Vijver, B. N.J.M. Gremmen, L. Beyens, and R. Le Cohu 2004b. “Pinnularia sofia Van de Vijver \& Le Cohu spec. nov., a new spine-bearing, chain-forming Pinnularia species from the sub-Antarctic region.” Diatom Research 19: 103-114.

doi:10.1080/0269249X.2004.9705610.

Van de Vijver, B., N.J.M. Gremmen, and L. Beyens 2005. “The genus Stauroneis (Bacillariophyceae) in the Antarctic Region.” Journal of Biogeography 32: 1791-1798. doi:10.1111/j.1365-2699.2005.01325.x.

Van de Vijver, B., and N.J.M. Gremmen 2006. “Three new moss-inhabiting diatom species from sub-Antarctic Marion Island.” Diatom Research 21: 427-439.

doi:10.1080/0269249X.2006.9705680. 
Van de Vijver, B., N.J.M. Gremmen, and V. Smith 2008. “Diatom communities from the subAntarctic Prince Edward Islands: diversity and distribution patterns.” Polar Biology 31: 795808. doi:10.1007/s00300-008-0418-z.

Van de Vijver, B., and R. Zidarova 2011. “Five new taxa in the genus Pinnularia sectio Distantes (Bacillariophyta) from Livingston Island (South Shetland Islands).” Phytotaxa 24: 39-50.

Van de Vijver, B. 2012. “Aulacoseira principissa sp. nov., a new 'centric’ diatom species from the sub-Antarctic region.” Phytotaxa 52: 33-42 (doi: 10.11646/phytotaxa.52.1.5). Van de Vijver, B., B. Chattová, D. Metzeltin, and M. Lebouvier 2012. “The genus Pinnularia (Bacillariophyta) on Ile Amsterdam (TAAF, Southern Indian Ocean).” Nova Hedwigia, Beihefte 141: 201-236.

Van de Vijver, B. 2014 “Analysis of the type material of Navicula brachysira Brébisson with the description of Brachysira sandrae, a new raphid diatom (Bacillariophyceae) from Iles Kerguelen (TAAF, sub-Antarctica, southern Indian Ocean).” Phytotaxa 184: 139-147. http://dx.doi.org/10.11646/phytotaxa.184.3.3

Van de Vijver, B., M. de Haan, and H. Lange-Bertalot 2014. "Revision of the genus Eunotia (Bacillariophyta) in the Antarctic Region.” Plant Ecology and Evolution 147: 256-284 (doi: 10.5091/plecevo.2014.930).

Van de Vijver, B., H. Lange-Bertalot, C.E. Wetzel, and L. Ector 2017. “Michelcostea, a new diatom genus (Bacillariophyta) from the sub-Antarctic Region.” Nova Hedwigia, Beihefte 146: 125-136. https://doi.org/10.1127/1438-9134/2017/125.

Van de Vijver B., and S. Dessein 2018. “Cyclotella deceusteriana, a new centric diatom species (Bacillariophyta) from the sub-Antarctic Region.” Phytotaxa 333: 108-116. 
Van de Vijver, B., C.E. Wetzel, and L. Ector 2018. “Analysis of the type material of Planothidium delicatulum (Bacillariophyta) with the description of two new Planothidium species from the sub-Antarctic Region.” Fottea 18: 200-211. doi: 10.5507/fot.2018.006. Van de Vijver, B. 2019. "Revision of the Psammothidium manguinii complex (Bacillariophyta) in the sub-Antarctic Region with the description of four new taxa.” Fottea 19: 90-106. http://doi.org/ 10.5507/fot.2019.001.

Van der Werff, A. 1955. “A new method of cleaning and concentrating diatoms and other organisms.” Verhandlungen der Internationalen Vereinigung für Theoretische und Angewandte Limnologie 12: 276-277.

Zidarova, R., K. Kopalová, and B. Van de Vijver 2012. “The genus Pinnularia (Bacillariophyta) excluding the section Distantes on Livingston Island (South Shetland Islands) with the description of twelve new taxa.” Phytotaxa 44: 11-37. doi:10.11646/phytotaxa.44.1.2.

Zidarova, R., K. Kopalová, and B. Van de Vijver 2016. “Diatoms from the Antarctic Region. Maritime Antarctica.” Iconographia Diatomologica 24: 1-504. 


\section{Figure captions}

Figures 1-19: Pinnularia schoelynckiana sp. nov. LM pictures taken from the holotype population (sample B-3) from Val Travers (Grande Terre, Iles Kerguelen). 1. Frustule in girdle view. 2-19. LM. Valve views. Scale bar represents $10 \mu \mathrm{m}$.

Figures 20-26: Pinnularia schoelynckiana sp. nov. SEM pictures taken from the holotype population (sample B-3) from Val Travers (Grande Terre, Iles Kerguelen). 20. External view of an entire valve. 21. Mantle view of an individual valve showing the large hyaline edge of the mantle. 22. External view of the central area. 23. External view of a valve apex showing the terminal raphe fissure. 24. Internal view of an entire valve. 25. Internal view of the central area with the interrupted raphe branches. 26. Internal view of a valve apex showing the helictoglossa. Scale bars represent $10 \mu \mathrm{m}$ except for fig. 26 where scale bar is $5 \mu \mathrm{m}$. 


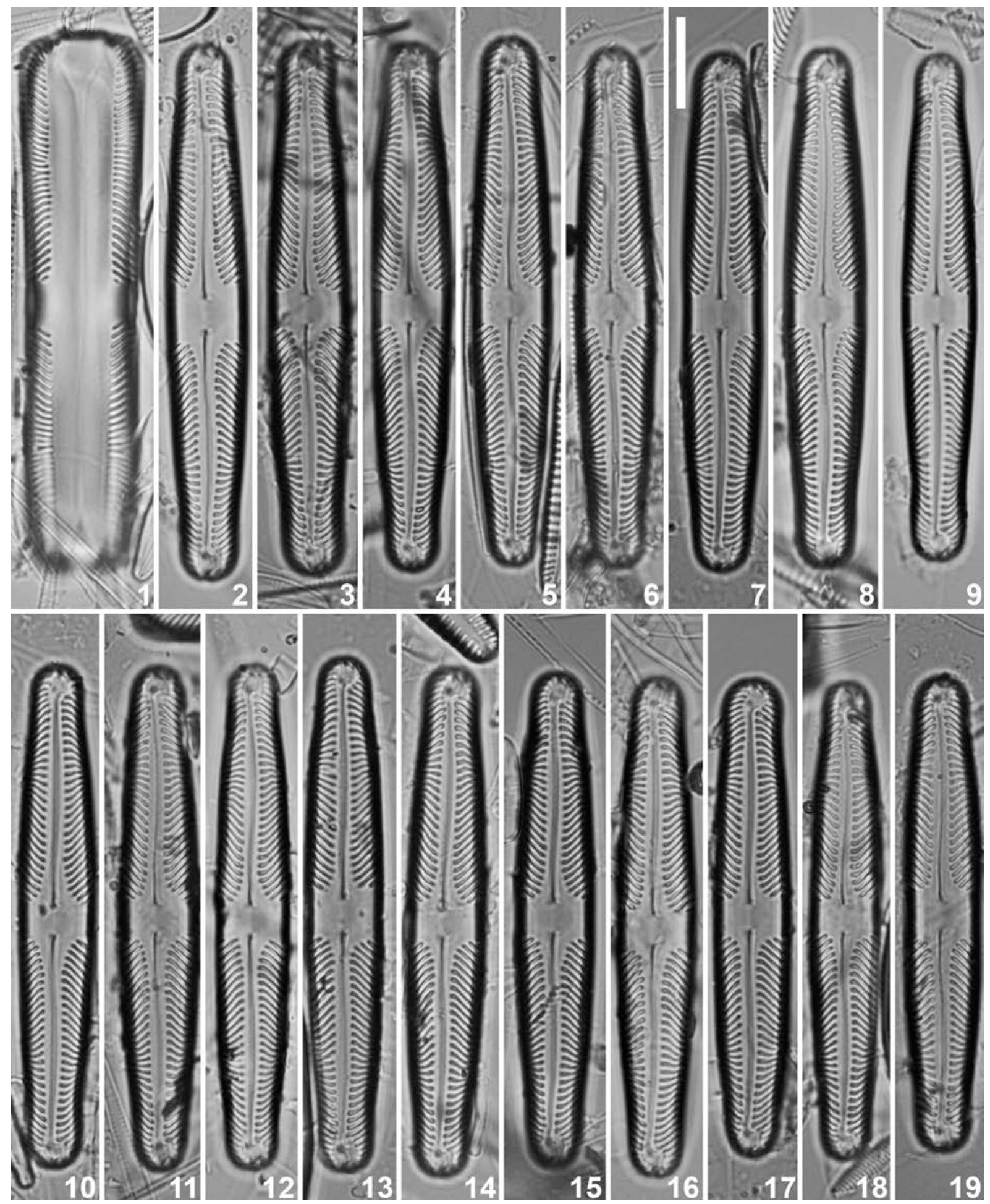




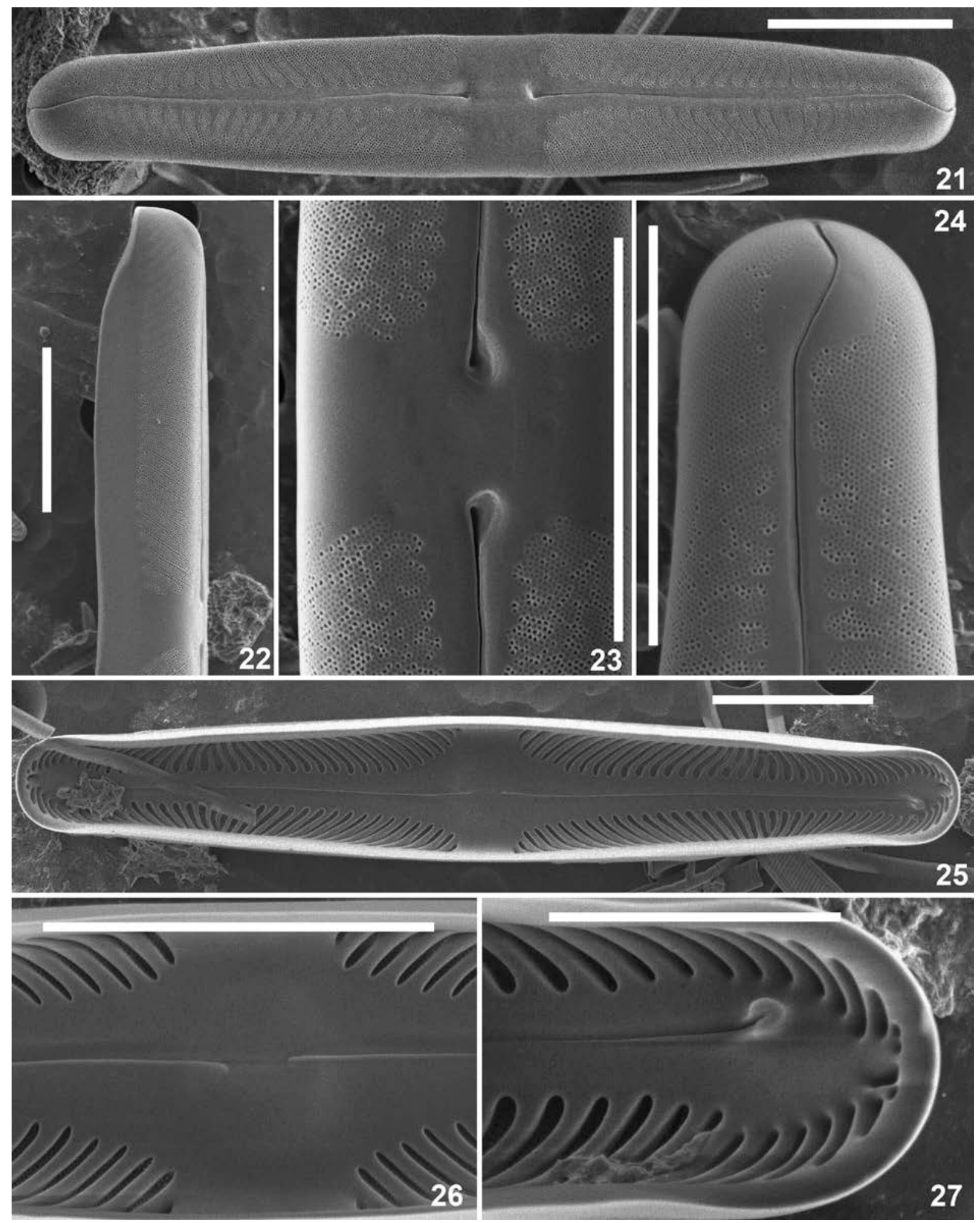

